\title{
The chemical composition of selected dried fruit pomaces and their effects on the growth performance and post-slaughter parameters of young turkeys
}

\author{
J. Juśkiewicz', J. Jankowski², Z. Zduńczyk ${ }^{1}$, K. Kołodziejczyk ${ }^{3}$, D. Mikulski ${ }^{2}$ and P. Zduńczyk2,4 \\ ${ }^{1}$ Institute of Animal Reproduction and Food Research, Polish Academy of Sciences, Tuwima 10, 10-748 Olsztyn, Poland \\ ${ }^{2}$ University of Warmia and Mazury in Olsztyn, Department of Poultry Science, Oczapowskiego 5, 10-718 Olsztyn, Poland \\ ${ }^{3}$ Lodz University of Technology, Institute of Chemical Technology of Food, Stefanowskiego 4/10, 90-924 Łodz, Poland
}

KEY WORDS: apple pomace, blackcurrant pomace, strawberry pomace, nutritive value, turkey

Received: 29 August 2014

Revised: 9 January 2015

Accepted: 16 March 2015

${ }^{4}$ Corresponding author:

e-mail: p.zdunczyk@pan.olsztyn.pl

\begin{abstract}
The objective of this study was to verify the hypothesis that adding dried fruit pomaces differing in their polyphenol contents to diets for young turkeys does not compromise bird performance. Young turkeys aged up to 15 weeks were fed diets containing a cellulose preparation (C) or $5 \%$ dried apple pomace (AP), blackcurrant pomace (BCP), strawberry pomace (SP), or seedless strawberry pomace (SSP). The crude protein content of AP was $6.64 \%$ and exceeded $15 \%$ in the remaining pomaces. In comparison with soyabean meal protein, the value of the essential amino acid index was lowest in AP $(78.6 \%)$, higher in SP and SSP (approximately 85\%) and highest in BCP (93.4\%). The crude fat content ranged from $2.63 \%$ in $\mathrm{AP}$ to $13.8 \%$ in $\mathrm{BCP}$, whereas the dietary fibre content was found to be in the range of $56.5 \%$ in $\mathrm{AP}$ to $62.9 \%$ in SP. AP, BCP, SP and SSP were characterized by different polyphenol concentrations: $5.75,12.43,11.51$ and $32.81 \mathrm{~g} \cdot \mathrm{kg}^{-1}$ of gallic acid, respectively. Dietary inclusion of $5 \%$ of dried fruit pomaces that increased the polyphenol content of the experimental diets by a maximum of $0.3 \mathrm{~g} \cdot \mathrm{kg}^{-1}$ relative to the control diet did not affect feed intake at the beginning or at the end of the feeding trial. In comparison with the cellulose-supplemented diet, the inclusion of fruit pomaces that increased the dietary polyphenol content did not impair the growth performance of turkeys or feed conversion. Production parameters, including slaughter results, were not affected by the higher polyphenol content or the higher antioxidant potential of blackcurrant and strawberry pomaces, compared with apple pomace.
\end{abstract}

\section{Introduction}

In intensive poultry production, excessive concentrations of indigestible structural carbohydrates (non-starch polysaccharides, NSPs) can lower feed intake and nutrient availability (Mateos et al., 2012). The crude fibre content of standard cereal-soyabean diets for young chickens and turkeys is relatively low at approximately 3.5\% (Jankowski et al., 2009;
Mateos et al., 2012), which is significantly below the $6 \%$ threshold tolerated by fast-growing birds (Zduńczyk et al., 2010). For this reason, moderate addition of selected high-fibre components to cerealsoyabean diets enhances gastrointestinal functions in birds (Mateos et al., 2012). Dried fruit pomaces, a rich source of NSPs and biologically active compounds, could be recommended supplements for poultry diets. 
The antioxidant properties of fruit provitamins and vitamins ( $\beta$-carotene, vitamins $\mathrm{C}$ and $\mathrm{E}$ ) and the presence of folic acid in fruit prevent the development of various diseases in humans (Esfahani et al., 2011). Many of these compounds are retained in pomace, which is why fruit pomaces are used in various biotechnological processes to produce health-promoting phytochemicals (Kołodziejczyk et al., 2007; Kandari and Gupta, 2012).

The growth of horticulture industries worldwide generates enormous quantities of fruit wastes, mostly pomaces from juice pressing, whose amount is estimated at $25 \%$ to $40 \%$ of total processed fruits (Bhushan et al., 2008). More than 1.5 million tons of apples are used in juice production in Poland (Kołodziejczyk et al., 2007). Only $20 \%$ of the resulting thousands of tons of pomace is used in animal nutrition (Dhillon et al., 2013). To date, fruit pomace has been used in poultry nutrition only locally, mostly in developing countries, to reduce feed costs (Matoo et al., 2001). Fruit pomace can be used more extensively in dried form.

The past decade has witnessed numerous research studies indicating that dried fruit pomaces can be effectively used in poultry nutrition, mostly grape pomaces that are produced in large quantities and can be effectively incorporated in maizesoyabean basal diets for broiler chickens (Goni et al., 2007). Fruit pomaces exerted beneficial effects on pigs by increasing Lactobacillus counts in the caecum and improving blood parameters (Sehm et al., 2011). In poultry, long-term administration of dried apple pomace improved the reproductive performance of breeder roosters, including several sperm characteristics (Akhlaghi et al., 2014).

Dried fruit pomaces contain $40 \%$ to $80 \%$ dietary fibre, and they are a rich source of polyphenolic compounds whose content and composition are determined by the raw material and the applied processing technology (Jarosławska et al., 2011). Animal nutritionists have traditionally regarded polyphenols as antinutrients due to the adverse effects of proanthocyanidin, a type of polyphenol, on protein digestibility, but recent experiments revealed that only a high content of polyphenolic extracts in chicken diets $\left(2.5 \mathrm{~g} \cdot \mathrm{kg}^{-1}\right.$ or more $)$ significantly reduced ileal digestibility of protein, lowered weight gains and negatively affected feed conversion in birds (Chamorro et al., 2013).

Turkeys' responses to varied polyphenol concentrations in the diet remain fairly unknown due to the general scarcity of research in this area. This is an important consideration in analyses compar- ing the dietary applications of berry fruit pomaces, including currant and strawberry pomaces, with apple pomaces that are more abundant in polyphenols (Jarosławska et al., 2011; Sójka et al., 2013). Due to their antioxidant properties, polyphenols can prevent lipid oxidation in broiler diets containing high levels of unsaturated fatty acids (Goni et al., 2007).

The objective of this study was to determine whether diets for young turkey poults can be supplemented with $5 \%$ dried fruit pomaces, including the most extensively researched apple pomace and lesser-known blackcurrant and strawberry pomaces, without compromising feed conversion and the body weight gains of birds.

\section{Material and methods}

\section{Fruit pomaces}

Dried apple pomace (AP), blackcurrant pomace (BCP) and strawberry pomace (SP), dried in an SB-1.5 rotary drum dryer for biomass residues, were supplied by Agro-Bio-Produkt Sp. z o.o. (Grądkowice, Poland). Seedless strawberry pomace (SSP) was supplied by Polfarmex (Łódź, Poland) as a by-product of seed separation in the oil production process. SSP had a seed content of less than 5\% and was dried in a vacuum dryer at $70^{\circ} \mathrm{C}$ for $8 \mathrm{~h}$. Each fruit pomace was ground in a hammer mill with a screen size of $4 \mathrm{~mm}$ (Jesma Co., Sprout Matador, Denmark), at $3000 \mathrm{rpm}$.

\section{Birds and management}

The experiment was carried out at the Research Laboratory of the Department of Poultry Science, University of Warmia and Mazury in Olsztyn (Poland). All experimental procedures were approved by the Local Animal Care and Use Committee (Olsztyn, Poland) and the study was carried out in accordance with EU Directive 2010/63/EU for animal experiments. The temperature and lighting programmes were consistent with the recommenda-

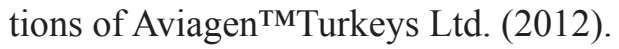

Five hundred and twenty-five Big 7 female turkeys were divided into 5 groups of 105 birds each. Each group was kept in 7 pens of 15 birds per pen (7 replicates per group). Every pen was equipped with an automatic feeder and a bell-type drinker and both water and feed were provided ad libitum. The experiment began when the turkeys were 1 day old and ended when the birds reached the age of 15 weeks. 


\section{Experimental design and diets}

The nutritive value of five experimental diets for three phases of feeding, whose composition is presented in Table 1, was consistent with or somewhat higher than turkey nutrient requirements (NRC, 1994). The levels of protein and amino acids in dried fruit pomaces were taken into account when balancing the diets for total protein and major amino acids. Powdered cellulose (Vitacel ${ }^{\circledR}$ ) was used as the control component to bring crude fibre concentrations in the control diet to the level found in the diet containing dried apple pomace. All diets were supplemented with Ronozyme P (0.01\%) and Ronozyme Wx $(0.02 \%)$ as a source of phytase and xylanase.

The nutrient content of diets was calculated based on the analysed chemical composition of fruit pomaces and according to the Poultry Feeding Standards (Smulikowska and Rutkowski, 2005). The diets contained $5 \%$ of the dried fruit pomaces in all feed- ing phases. In the first two feeding phases (weeks 1-4 and 5-10), the diets contained only soyabean oil to level out their energetic value. In the third feeding phase, part of the soyabean oil $(2.5 \%)$ was replaced with linseed oil to increase n-3 PUFA concentrations in meat.

\section{Measurements and calculations}

A three-phase feeding programme was applied in the study. Diet intake and feed conversion ratio (FCR) were determined in the periods of days 1-28, 1-70 and 71-105; the turkeys were weighed on the last day of each period. Mortality rates, including their causes, were monitored every day. A pen of 32 birds was considered an experimental unit.

The quality of protein in fruit pomaces was determined based on the essential amino acid index (EAAI) and the first-limiting AA, with soyabean protein as the reference standard.

Table 1. Composition and nutritional value of diets fed to turkeys aged 1-4, 5-10 and 11-15 weeks

\begin{tabular}{|c|c|c|c|c|c|c|c|c|c|c|c|c|c|c|c|}
\hline \multirow{2}{*}{ Indices } & \multicolumn{5}{|c|}{ Weeks $1-4$} & \multicolumn{5}{|c|}{ Weeks 5-10 } & \multicolumn{5}{|c|}{ Weeks $11-15$} \\
\hline & $\mathrm{C}$ & $\mathrm{AP}$ & $\mathrm{BCP}$ & SP & SSP & $\mathrm{C}$ & AP & $\mathrm{BCP}$ & $\mathrm{SP}$ & SPP & $\mathrm{C}$ & $\mathrm{AP}$ & $\mathrm{BCP}$ & SP & SSP \\
\hline \multicolumn{16}{|l|}{ Component, \% } \\
\hline wheat & 24.92 & 21.84 & 23.09 & 23.01 & 23.12 & 31.39 & 28.27 & 29.51 & 29.45 & 29.56 & 58.54 & 55.33 & 57.61 & 57.58 & 57.77 \\
\hline maize & 20.00 & 20.00 & 20.00 & 20.00 & 20.00 & 18.00 & 18.00 & 18.00 & 18.00 & 18.00 & - & - & - & - & - \\
\hline soyabean meal & 40.86 & 40.86 & 40.86 & 40.86 & 40.86 & 36.00 & 36.00 & 36.00 & 36.00 & 36.00 & 30.83 & 31.03 & 29.40 & 29.34 & 29.15 \\
\hline potato protein & 5.00 & 5.10 & 4.26 & 4.23 & 4.12 & 4.62 & 4.72 & 3.88 & 3.84 & 3.73 & - & - & - & - & - \\
\hline vitacel & 2.32 & - & - & - & - & 2.31 & & & & & 2.33 & - & - & - & - \\
\hline apple pomace & - & 5.00 & - & - & - & - & 5.00 & - & - & - & - & 5.00 & - & - & - \\
\hline blackcurrant pomace & - & - & 5.00 & - & - & - & - & 5.00 & - & - & - & - & 5.00 & - & - \\
\hline $\begin{array}{l}\text { seedle } \\
\text { poma }\end{array}$ & - & - & - & 5.00 & 5.00 & - & - & - & 5.00 & 5.00 & - & - & - & 5.00 & 5.00 \\
\hline strawberry pomace & - & - & - & - & 5.00 & - & - & - & - & 5.00 & - & - & - & - & 5.00 \\
\hline soyabean oil & 1.64 & 1.94 & 1.53 & 1.62 & 1.62 & 2.92 & 3.24 & 2.83 & 2.92 & 2.92 & 2.84 & 3.17 & 2.52 & 2.60 & 2.60 \\
\hline linseed oil & - & - & - & - & - & - & - & - & - & - & 2.50 & 2.50 & 2.50 & 2.50 & 2.50 \\
\hline sodium bicarbonate & 0.10 & 0.10 & 0.10 & 0.10 & 0.10 & 0.10 & 0.10 & 0.10 & 0.10 & 0.1 & 0.10 & 0.10 & 0.10 & 0.10 & 0.10 \\
\hline fodder salt & 0.25 & 0.25 & 0.25 & 0.25 & 0.2 & 0.25 & 0.25 & 0.25 & 0.25 & 0.25 & 0. & 0.14 & 0.14 & 0.14 & 0.14 \\
\hline limes & & 1.77 & 1.77 & 1. & 1.7 & & 1.58 & & & 1. & & 1.22 & 1.23 & 1.23 & 1.23 \\
\hline $\begin{array}{l}\text { monocalcium } \\
\text { phosphate }\end{array}$ & 1.98 & 2.0 & 1.99 & 1.99 & 1.99 & 1.79 & 1.82 & 1.81 & 1.81 & 1.81 & 0.55 & 0.57 & 0.57 & 0.57 & 0.57 \\
\hline DL-me & & 0.3 & & & 0.3 & & 0.32 & & & $0.3^{3}$ & & 0.19 & 0.18 & 0.18 & 0.18 \\
\hline L-lysin & 0.30 & 0.29 & 0.30 & 0.31 & 0.31 & 0.27 & 0.25 & 0.27 & 0.28 & 0.28 & 0.29 & 0.28 & 0.28 & 0.29 & 0.29 \\
\hline L-threonine & - & - & - & - & - & - & - & - & - & - & 0.07 & 0.07 & 0.07 & 0.07 & 0.07 \\
\hline vitamin-miner & 0.50 & 0.50 & 0.50 & 0.50 & 0.50 & 0.45 & 0.45 & 0.45 & 0.45 & 0.4 & 0.40 & 0.40 & 0.40 & 0.40 & 0.40 \\
\hline \multicolumn{16}{|l|}{ Nutritive value } \\
\hline crude protein & 27.50 & 27.50 & 27.50 & 27.50 & 27.50 & 25.50 & 25.50 & 25.50 & 25.50 & 25.50 & 21.50 & 21.50 & 21.50 & 21.50 & 21.50 \\
\hline crude fibre & & 4.10 & 5.12 & & 4.67 & & 3.96 & 4.99 & 4.53 & & 3.96 & 3.96 & 4.94 & 4.48 & 4.48 \\
\hline lysine & & 1.74 & 1.74 & 1.74 & 1.74 & & 1.58 & 1.58 & 1.58 & 1.58 & 1.25 & 1.25 & 1.25 & 1.25 & 1.25 \\
\hline Met + Cys & 1.19 & 1.19 & 1.19 & 1.19 & 1.19 & 1.11 & 1.11 & 1.11 & 1.11 & 1.11 & 0.86 & 0.86 & 0.86 & 0.85 & 0.85 \\
\hline threonine & 1.06 & 1.06 & 1.05 & 1.05 & 1.05 & 0.97 & 0.97 & 0.97 & 0.97 & 0.97 & 0.80 & 0.80 & 0.80 & 0.80 & 0.80 \\
\hline $\mathrm{Ca}$ & 1.25 & 1.25 & 1.25 & 1.25 & 1.25 & 1.15 & 1.15 & 1.15 & 1.15 & 1.15 & 0.75 & 0.75 & 0.75 & 0.75 & 0.75 \\
\hline$P$ & 0.58 & 0.58 & 0.58 & 0.58 & 0.58 & 0.54 & 0.54 & 0.54 & 0.54 & 0.54 & 0.30 & 0.30 & 0.30 & 0.30 & 0.30 \\
\hline $\begin{array}{l}\text { metabolizable energy, } \\
\qquad \mathrm{MJ} \cdot \mathrm{kg}^{-1}\end{array}$ & 11.28 & 11.28 & 11.28 & 11.28 & 11.28 & 11.8 & 11.8 & 11.8 & 11.8 & 11.8 & 12.54 & 12.54 & 12.54 & 12.54 & 12.54 \\
\hline
\end{tabular}

C - cellulose, AP - apple pomace, BCP - blackcurrent pomace, SP - strawberry pomace, SSP - seedless strawberry pomace; ${ }^{1} 0.5 \%$ of the Extramix provided per $\mathrm{kg}$ of diet: IU: all trans-retinol acetate 13.000, cholecalciferol 3.000; mg: all-rac-a-tocopheryl acetate 40 , vit. $\mathrm{K}_{3} 2$, vit. $B_{1} 2$, vit. $B_{2} 8$, vit. $B_{6} 3.5$, niacin 65 , pantothenic acid 18, folic acid 1.5, biotin 0.2, choline chloride 400, Mn 100, Zn 80, Fe 50, Cu 8, 10.8 , Se 0.3 
At the end of the trial, seven birds representing the average body weight of each group were selected, tagged and fasted for $8 \mathrm{~h}$. After slaughter, the carcasses were scalded, plucked and eviscerated. The weights of the breast, thigh, drumstick, giblets (gizzard, liver and heart) and abdominal fat were calculated as relative (\%) weight of the carcass. After $24 \mathrm{~h}$ of chilling the carcass, the $\mathrm{pH}$ and colour parameters of breast muscle were determined.

The $\mathrm{pH}$ of breast muscles was measured $24 \mathrm{~h}$ post mortem (Testo GmbH 206-pH2 meter). The Hunter L* (lightness, a lower value indicates a darker colour), $a^{*}$ (redness, a higher positive value indicates a higher contribution of redness) and $b^{*}$ (yellowness, a higher value indicates a higher contribution of yellowness) values were determined using a MiniScan XE Plus colour difference meter (Hunter Associates Laboratory, Inc., Reston, VA, USA). The average of three readings taken from a cross-section of a muscle free from colour defects, bruising and haemorrhages was recorded.

\section{Chemical analyses}

Fruit pomace samples were analysed in duplicate for dry matter (DM), crude protein (CP), fat, crude fibre, ash and dietary fibre using AOAC (2005) methods: 934.01, 976.05, 920.39, 978.10, 942.05 and 985.29 , respectively. The samples were mineralized in a mixture (3:1) of nitric and perchloric acids (Merck, Germany) to determine the mineral composition of pomaces. Weighed samples were mineralized in a VELP DK 20 electric aluminium heating block with selectable temperatures (VELP Scientifica, Italy). The $\mathrm{Ca}, \mathrm{K}, \mathrm{Mg}$ and $\mathrm{Na}$ contents of mineralized samples were determined by flame atomic absorption spectrometry (acetylene-air flame). The analysis was performed using a Unicam 939 Solar atomic absorption spectrophotometer equipped with an Optimus data station, background correction system (deuterium lamp) and cathode lamps. The P content of mineralized samples was determined by colourimetry using ammonium molybdate, Na sulphate and hydroquinone. Absorbance was measured in a VIS 6000 spectrophotometer (Krüss-Optronic, Germany) at a wavelength of $\lambda=610 \mathrm{~mm}$.

Amino acid concentrations were determined by post-column derivatization with ninhydrin in an AAA-400 Automatic Amino Acid Analyser (INGOS Ltd., Czech Republic). Before analysis, the samples were hydrolysed with $6 \mathrm{~N}$ hydrochloric acid for $24 \mathrm{~h}$ at $110^{\circ} \mathrm{C}$ (procedure 994.12; AOAC, 2005). Methionine and cysteine were determined as methionine sulphone and cysteic acid after cold per- formic acid oxidation before hydrolysis (procedure 994.12). Tryptophan was determined by hydrolysing the samples with barium hydroxide, carrying out a colour reaction with $p$-dimethylaminobenzaldehyde and spectrophotometrically measuring the absorbance of the product at $590 \mathrm{~nm}$.

The polyphenol content was determined spectrophotometrically by the Folin-Ciocalteau method (FC polyphenols) based on the reducing capacity of phenolic compounds. The standard curve was developed with the use of gallic acid according to the method of Singleton and Rossi (1965).

\section{Statistical analysis}

The statistical analysis was performed using oneway analysis of variance (ANOVA), according to the GLM procedure for Statistica 8.0PL software (StatSoft Inc., 2007). Treatment effects were considered to be significant at $P \leq 0.05$. All data were expressed as mean values with a pooled standard error (SEM).

\section{Results}

The evaluated fruit pomaces differed in their proximate composition, including the content of total protein, crude fat and crude fibre (Table 2). In comparison with the remaining pomaces, AP was characterized by a lower content of crude protein and crude fat and relatively low concentrations of crude ash. In comparison with AP, crude fibre levels were lower in BCP and higher in SP and SSP. The analysed pomaces had similar dietary fibre levels that ranged from $56.5 \%$ in AP to more than $62 \%$ in $\mathrm{BCP}$ and SP. In comparison with the standard (SP), (SSP) contained less crude ash, more crude protein, less crude and dietary fibres.

Table 2. Chemical composition of dried fruit pomaces, $\%$

\begin{tabular}{lcccc}
\hline Indices & $\mathrm{AP}$ & $\mathrm{BCP}$ & $\mathrm{SP}$ & $\mathrm{SSP}$ \\
\hline Proximate composition & & & & \\
$\quad$ dry matter & 92.4 & 93.7 & 93.2 & 94.8 \\
$\quad$ crude ash & 1.10 & 3.89 & 8.01 & 5.86 \\
$\quad$ crude protein & 6.64 & 15.5 & 16.4 & 17.8 \\
$\quad$ crude fat & 2.63 & 13.8 & 10.4 & 9.64 \\
Fibre fractions & & & & \\
$\quad$ crude fibre (CF) & 22.0 & 19.8 & 31.4 & 26.3 \\
dietary fibre (DF) & 56.5 & 62.4 & 62.97 & 59.6 \\
Macroelements & & & & \\
Ca & 0.09 & 0.36 & 0.37 & 0.26 \\
K & 0.23 & 0.39 & 0.15 & 0.15 \\
P & 0.16 & 0.33 & 0.43 & 0.41 \\
Mg & 0.04 & 0.17 & 0.10 & 0.06 \\
Na & $<0.01$ & $<0.01$ & $<0.01$ & $<0.01$ \\
\hline
\end{tabular}

AP, BCP, SP, SSP - see Table 1 
Table 3. Amino acid profile of protein from dried fruit pomaces vs soyabean protein, \% crude protein (CP)

\begin{tabular}{lccccc}
\hline $\begin{array}{l}\text { Amino acid, } \\
\% \text { CP }\end{array}$ & $\begin{array}{l}\text { Soyabean } \\
\text { meal }^{1}\end{array}$ & AP & BCP & SP & SSP \\
\hline Met & 1.32 & 0.76 & 1.27 & 1.13 & 1.30 \\
Cys & 1.45 & 1.01 & 1.71 & 1.11 & 1.16 \\
Met + Cys & 2.77 & 1.77 & 2.99 & 2.26 & 2.46 \\
Lys & 6.03 & 4.81 & 5.89 & 4.56 & 4.79 \\
Thr & 3.91 & 3.46 & 4.22 & 3.72 & 3.67 \\
Trp & 1.34 & 0.65 & 0.85 & 0.82 & 1.05 \\
Arg & 7.14 & 4.94 & 7.83 & 6.36 & 5.21 \\
lle & 4.53 & 3.92 & 5.81 & 4.37 & 4.09 \\
Leu & 7.57 & 7.30 & 7.43 & 7.16 & 7.16 \\
Val & 4.77 & 4.78 & 4.41 & 5.02 & 5.11 \\
His & 2.60 & 2.77 & 2.97 & 2.74 & 2.23 \\
Phe & 5.03 & 3.89 & 4.63 & 3.88 & 4.18 \\
Tyr & 3.45 & 2.17 & 3.16 & 2.23 & 1.77 \\
Phe + Tyr & 8.48 & 6.06 & 7.79 & 6.11 & 5.95 \\
Gly & 4.21 & 4.84 & 6.35 & 5.03 & 5.48 \\
Ser & 4.98 & 4.62 & 4.78 & 4.51 & 4.60 \\
Pro & 5.00 & 3.88 & 4.11 & 3.65 & 3.86 \\
Ala & 4.35 & 4.90 & 4.87 & 4.85 & 4.37 \\
Asp & 11.37 & 11.0 & 10.9 & 9.87 & 10.1 \\
Glu & 18.0 & 14.5 & 18.9 & 15.0 & 18.0 \\
EAAl & 100 & 78.6 & 93.4 & 85.6 & 84.9 \\
First limiting & 100 & Trp (49) & Trp (63) & Trp (61) & Tyr (78) \\
AA, \% & & & & & \\
\hline AP BCP SPSP & & & & &
\end{tabular}

AP, BCP, SP, SSP - see Table $1:{ }^{1}$ soyabeans analysed in a previous study (Zduńczyk et al., 2014); ${ }^{2}$ the essential amino acid index (EAAI) and the first-limiting AA were determined using soyabean protein as a reference standard

AP was characterized by lower calcium and magnesium concentrations in comparison with the remaining pomaces. The highest potassium and magnesium levels were noted in BCP, but the observed differences were smaller than those noted between SP and SSP vs AP.

AP was characterized by the lowest content of selected essential amino acids, including methionine, tryptophan and isoleucine, whereas the remaining pomaces had similar amino acid profiles (Table 3). The highest cysteine, lysine and arginine concentrations were found in BCP. In comparison with soyabean meal protein, $\mathrm{BCP}$ protein was characterized by the highest levels of essential amino acids, which were higher than in SP and SSP, and considerably higher than in AP. In comparison with soyabean protein, tryptophan limited the biological value of protein in the analysed fruit pomaces, excluding SSP.

The compared pomaces differed in their polyphenol contents (Table 4). Polyphenol concentrations were the lowest in AP, approximately 2-fold higher in $\mathrm{BCP}$ and SP, and almost 6-fold higher in SSP.
Table 4. Polyphenol concentrations in dried fruit pomaces and in the experimental diets, $\mathrm{g} \cdot \mathrm{kg}^{-1}$

\begin{tabular}{lccccc}
\hline $\begin{array}{l}\text { Polyphenol } \\
\text { concentrations }\end{array}$ & C & AP & BCP & SP & SSP \\
\hline Dried fruit pomace & - & 5.75 & 12.43 & 11.51 & 32.81 \\
\multicolumn{7}{c}{ Diets fed to turkeys } & in three consecutive phases, weeks: \\
$1-4$ & 2.03 & 2.11 & 2.18 & 2.21 & 2.31 \\
$5-10$ & 1.82 & 1.88 & 2.03 & 1.98 & 2.10 \\
$11-15$ & 1.27 & 1.45 & 1.48 & 1.48 & 1.58 \\
\hline
\end{tabular}

C, AP, BCP, SP, SSP - see Table 1

Table 5. The growth performance of turkeys from 1 to 105 days of age

\begin{tabular}{lrrrrrrr}
$\begin{array}{l}\text { Feeding } \\
\text { phase, days }\end{array}$ & C & AP & BCP & SP & SSP & SEM & $P$ \\
\hline $\begin{array}{l}\text { Daily feed intake, g } \\
\text { 1-28 }\end{array} 49$ & 49 & 49 & 49 & 50 & 0.358 & 0.943 \\
$1-70$ & 163 & 159 & 160 & 165 & 163 & 0.948 & 0,515 \\
$1-105$ & 254 & 250 & 250 & 250 & 252 & 1.366 & 0.903
\end{tabular}

Body weight, $\mathrm{kg}$

$\begin{array}{rrrrrrrr}1 & 0.06 & 0.06 & 0.06 & 0.06 & 0.06 & 0.001 & 0.917 \\ 28 & 0.93 & 0.91 & 0.93 & 0.93 & 0.93 & 0.007 & 0.947 \\ 70 & 5.74 & 5.72 & 5.76 & 5.74 & 5.78 & 0.070 & 0.972 \\ 105 & 10.44 & 10.58 & 10.47 & 10.44 & 10.57 & 0.045 & 0.779\end{array}$

$\mathrm{FCR}, \mathrm{kg}$ of feed $/ \mathrm{kg}$ of BWG

\begin{tabular}{cccccccc}
$1-28$ & 1.49 & 1.50 & 1.49 & 1.48 & 1.60 & 0.007 & 0.895 \\
$1-70$ & 2.02 & 2.00 & 2.00 & 2.02 & 2.04 & 0.006 & 0.633 \\
$1-105$ & 2.57 & 2.51 & 2.54 & 2.52 & 2.58 & 0.013 & 0.539 \\
$\begin{array}{c}\text { Mortality, \% } \\
1-105\end{array}$ & 0.95 & 1.90 & 1.90 & 0.95 & 0.95 & - & - \\
\hline
\end{tabular}

C, AP, BCP, SP, SSP - see Table 1; FCR - feed convertion ratio, BWG - body weight gain

In all feeding phases, the dietary inclusion of dried fruit pomaces with different polyphenol contents did not affect feed intake (Table 5). Daily feed intake in the analysed groups was determined within a narrow range of 250-254 g during the 105-day feeding trial. Dietary treatments did not influence the growth rate of young birds. Body weights determined on successive weighing days between the ages of 1 day to 105 days were similar in all experimental groups. The final body weights of female turkeys were within a very narrow range of 10.4-10.6 kg. In all groups, the feed conversion ratio was similar in each feeding phase and throughout the feeding trial. The mortality rates of turkeys were very low in all groups (below $2 \%$ ).

No significant differences were found in such slaughter quality parameters as the yields of breast, thigh and drumstick meat, abdominal fat, or the $\mathrm{pH}$ and colour parameters of breast meat (Table 6). 
Table 6. Carcass characteristics of turkeys after 15 weeks of experimental feeding

\begin{tabular}{lrrrrrrr}
\hline Indices & C & AP & BCP & SP & SSP & SEM & $P$ \\
\hline Muscle, \% of carcass & & & & & & \\
breast & 23.6 & 23.6 & 24.2 & 24.1 & 24.2 & 1.591 & 0.880 \\
thigh & 10.3 & 10.0 & 10.8 & 10.4 & 10.6 & 0.740 & 0.287 \\
drumstick & 7.9 & 7.2 & 8.2 & 8.1 & 8.00 & 0.582 & 0.617 \\
$\quad$ total & 41.8 & 41.3 & 43.2 & 42.6 & 42.8 & 1.914 & 0.278 \\
$\begin{array}{l}\text { Giblets } \\
\text { of \% }\end{array}$ & 2.35 & 2.45 & 2.32 & 2.32 & 2.22 & 0.233 & 0.414 \\
$\begin{array}{l}\text { Abdominal fat, } \\
\text { \% of carcass }\end{array}$ & 2.10 & 2.19 & 2.05 & 1.94 & 1.92 & 0.429 & 0.739 \\
pH $_{\text {24h of breast }}$ & 5.67 & 5.70 & 5.88 & 5.72 & 5.69 & 0.213 & 0.313 \\
muscle & & & & & & & \\
Meat colour paramaters $^{2}$ & & & & & & \\
$\mathrm{~L}^{*}$ & 51.6 & 52.6 & 52.8 & 52.4 & 52.7 & 2.141 & 0.838 \\
a $^{*}$ & 5.2 & 5.7 & 5.1 & 5.4 & 4.8 & 0.984 & 0.461 \\
b $^{*}$ & 10.5 & 11.0 & 11.2 & 10.8 & 10.6 & 0.960 & 0.574 \\
\hline
\end{tabular}

C, AP, BCP, SP, SSP - see Table $1 ;{ }^{1}$ combined data for the gizzard, liver and heart; ${ }^{2} L^{*}-$ lightness, $a^{*}-$ redness, $b^{*}-$ yellowness

\section{Discussion}

Numerous authors have investigated the use of grape pomace (Goni et al., 2007) and apple pomace (Matoo et al., 2001; Figuerola et al., 2005) in animal nutrition. In our experiment, apple pomace was the least abundant in nutrients among the analysed dried fruit pomaces. The crude protein content and crude fat content of apple pomace was low $(6.64 \%$ and $2.63 \%$, respectively) and similar values were reported in other studies (Massini et al., 2013). The results of another experiment (Figuerola et al., 2005) indicate that the crude protein content of apple pomace can be lower than $5 \%$ of dry matter.

In one of the few experiments investigating the nutritive value of raspberry pomace for monogastric animals, its crude protein content was estimated at $10 \%$ (McDougall and Beames, 1994). The total protein content of strawberry pomace was found to be even higher at 19\% (Jarosławska et al., 2011). In comparison with apple pomace, higher concentrations of crude protein in berry fruit pomaces could be attributed to their higher seed content, which was estimated at $40 \%$ in strawberry pomace (Sójka et al., 2013 ) but only at $2 \%-3 \%$ in apple pomace (Carson et al., 1994). In our study, however, the nearly complete removal of seeds from strawberry pomace did not decrease, but actually increased its total protein content.

The compared fruit pomaces, in particular apple pomace, contained small amounts of mineral macroelements: $\mathrm{Ca}, \mathrm{P}, \mathrm{K}, \mathrm{Mg}$ and $\mathrm{Na}$. In berry fruit pomaces, Ca levels were slightly higher, whereas $\mathrm{P}$ and $\mathrm{K}$ concentrations were considerably lower than those noted by Helbig et al. (2008) in whole blackcurrant seeds. The differences in the mineral content of plants can be attributed to numerous factors, including soil nutrient levels and fertilization rate (Mayer, 1997).

In the current experiment, considerable differences were observed in the amino acid profiles of the analysed pomaces. In comparison with soyabean meal, the value of the essential amino acid index (EAAI) was lower in apple pomace, distinctly higher in strawberry pomace and very high in blackcurrant pomace. The observed high biological value of protein in blackcurrant pomace is consistent with the results of Helbig et al. (2008) in whose study the EAAI of blackcurrant seeds was equivalent to $76 \%$ of the EAAI of whole eggs. In the cited experiment and in our study, the first limiting amino acid that decreased protein quality in fruit pomaces was tryptophan, which is generally present in sufficient quantities in poultry diets.

In our experiment, considerable differences in crude fibre content and relatively small differences in dietary fibre (DF) content were noted in the analysed dried fruit pomaces. This indicates that the compared pomaces differ in their content of soluble fibre fractions such as hemicellulose and lignin, a small portion of which was measured as crude fibre. In this study, the DF content ranged from $56.5 \%$ in apple pomace to $63.0 \%$ in standard strawberry pomace, and was similar to the values reported by other authors. In other experiments, DF concentrations in apple and strawberry pomaces ranged from $50 \%$ to 61\% (Jarosławska et al., 2011; Dhillon et al., 2013).

Other studies indicate that the polyphenol content of apples, currants and strawberries varies in both fresh fruit (Vulic et al., 2011) and in dried fruit pomace (Suarez et al., 2010; Jarosławska et al., 2011). In this experiment, the total polyphenol content of apple pomace was below $6 \mathrm{~g} \cdot \mathrm{kg}^{-1}$ but it was more than twice as high in blackcurrant and strawberry pomaces that were dried in a rotary drum dryer. Polyphenol concentrations were several-fold higher in seedless strawberry pomace $\left(32.8 \mathrm{~g} \cdot \mathrm{kg}^{-1}\right)$. The above results suggest that strawberry flesh residues are more abundant in polyphenols than strawberry seeds.

In comparison with the control diet, the inclusion of fruit pomaces in diets fed to turkeys at the age of $1-4,5-10$ and $11-15$ weeks increased polyphenol concentrations by $0.08-0.28,0.06-0.28$, and $0.18-0.31 \mathrm{~g} \cdot \mathrm{kg}^{-1}$, respectively. The highest increase in polyphenol concentrations was noted in diets supplemented with strawberry pomace, and the 
lowest - in diets containing apple pomace. The above differences resulted from variations in the polyphenol content of pomaces incorporated into turkey diets. In the second and third feeding phases, clearly lower polyphenol concentrations in all diets resulted from lower soyabean meal levels. Soyabean and soyabean products are rich in polyphenols, in particular isoflavones (Malencic et al., 2012). The polyphenol content of wheat, whose share in turkey diets increased in the last feeding phase, is several times lower compared with fruit pomace (PerezJimenez et al., 2010).

The differences in the composition of experimental diets, including the increase in their total polyphenol content, did not affect feed intake, the growth rate of turkeys or feed conversion. In the study of Chamorro et al. (2013), the intestinal digestibility of protein and the growth rate of chickens were reduced only when dietary supplementation with grape polyphenol extract exceeded $2.5 \mathrm{~g} \cdot \mathrm{kg}^{-1}$. In our experiment, the maximum polyphenol content of diets given in the first feeding phase (weeks 1-4) and containing strawberry pomace $\left(2.31 \mathrm{~g} \cdot \mathrm{kg}^{-1}\right.$, in SSP) was lower than that reported by Chamorro et al. (2013). The above could explain why polyphenols from the fruit pomaces applied in our study did not negatively affect feed intake, feed conversion, or body weight gains of turkeys. In other experiments, the growth performance of chickens was not impaired when their diets were supplemented with apple pomace (Matoo et al., 2001) or grape pomace with a higher polyphenol content (Goni et al., 2007).

In earlier experiments performed on young hogs (McDougall and Beames, 1994), raspberry protein was characterized by a relatively high biological value $(\mathrm{BV}=79.3 \%)$, but very low digestibility (14.7\%). Consequently, only $1.5 \%$ of the $10 \%$ total crude protein content was digested. Low digestibility of pomace ingredients can exert a minor influence on the nutritive value of a diet due to the low content of fruit pomace. In our experiment, the use of seedless strawberry pomace contributed to the highest fruit protein content $(0.9 \%)$ of the diet, which accounted for $4.2 \%$ of total dietary protein in the third feeding phase. This dilution of soyabean protein and wheat protein with fruit pomace protein had no effect on nutrient utilization or the growth performance of turkeys. In another experiment (Jankowski et al., 2012), moderate dilution of standard turkey diets with pelleted or whole wheat $(18 \%$ on average, between weeks 5 and 18) decreased protein concentrations by $5.8 \%$ in comparison with the control diet. The above dilution had no effect on the final body weights or muscle yield of birds, but it improved feed efficiency. Fruit pomaces contained in turkey diets did not deteriorate bird performance for a similar reason, namely low digestibility of crude protein.

The results of few experiments indicate that the supplementation of poultry diets with purified flavonoids can modulate meat quality parameters such as colour and pH (Jiang et al., 2007) or fatty acid composition (Kamboh and Zhu, 2013). In the current experiment, fruit pomaces with differing polyphenol contents had no effect on the yields of major muscles or on the $\mathrm{pH}$ and colour parameters of breast meat.

\section{Conclusions}

The results of this study indicate that blackcurrant and strawberry pomaces contain more crude protein with a more desirable amino acid profile and more polyphenols than apple pomace. The differences in the chemical composition of fruit pomaces, including considerable differences in their polyphenol content, did not influence feed intake or feed conversion in the experimental birds. Dietary supplementation with 5\% fruit pomace in three successive feeding phases is not a factor that negatively affects growth rate, feed conversion or slaughter quality parameters in female turkeys poults.

\section{Acknowledgements}

This research was carried out as part of the research project BIOFOOD - 'Innovative, Functional Products of Animal Origin' No. POIG.01.01.02014-090/09 co-financed by the European Union from the European Regional Development Fund within the Innovative Economy Operational Programme 2007-2013.

\section{References}

Akhlaghi A., Ahangari Y.J., Zhandi M., Peebles E.D., 2014. Reproductive performance, semen quality, and fatty acid profile of spermatozoa in senescent broiler breeder roosters as enhanced by the long-term feeding of dried apple pomace. Anim. Reprod. Sci. 147, 64-73

AOAC, 2005. Association of Official Analytical Chemists, Official Methods of Analysis. $18^{\text {th }}$ Edition. Arlington, VA

Aviagen Turkeys, 2012. Management Essentials for Commercial Turkeys. B.U.T. 7 Commercial Performance Goals. 6 $6^{\text {th }}$ Edition. Aviagen Turkeys www.aviagenturkeys.com/us/products/but. aspx

Bhushan S., Kalia K., Sharma M., Singh B., Ahuja P.S., 2008. Processing of apple pomace for bioactive molecules. Crit. Rev. Biotechnol. 28, 285-296 
Carson K.J., Collins J.L., Penfield M.P., 1994. Unrefined, dried apple pomace as a potential food ingredient. J. Food Sci. 59, 1213-121

Chamorro S., Viveros A., Centeno C., Romero C., Arija I., Brenes A., 2013. Effects of dietary grape seed extract on growth performance, amino acid digestibility and plasma lipids and mineral content in broiler chicks. Animal 7, 555-561

Dhillon G.S., Kaur S., Brar S.K., 2013. Perspective of apple processing wastes as low cost substrates for bioproduction of high value products: A review. Renew. Sustain. Energy Rev. 27, 789-805

Esfahani A., Wong J.M., Truan J., Villa C.R., Mirrahimi A., Srichaikul K., Kendall C.W., 2011. Health effects of mixed fruit and vegetable concentrates: a systematic review of the clinical interventions. J. Amer. Coll. Nutr. 30, 285-294

Figuerola F., Hurtado L.M., Estevez A.M., Chiffelle I., Asenjo F., 2005. Fibre concentrates from apple pomace and citrus peel as potential fibre source for food enrichment. Food Chem. 91, 395-401

Goni I., Brenes A., Centeno C., Viveros A., Saura-Calixto F., Rebole A., Arija I., Estevez R., 2007. Effect of dietary grape pomace and vitamin $\mathrm{E}$ on growth performance, nutrient digestibility, and susceptibility to meat lipid oxidation in chickens. Poultry Sci. 86, 508-516

Helbig D., Böhm V., Wagner A., Schubert R., Jahreis G., 2008. Berry seed press residues and their valuable ingredients with special regard to black currant seed press residues. Food Chem. 111, 1043-1049

Jankowski J., Juskiewicz J., Gulewicz K., Lecewicz A., Slominski B.A., Zduńczyk Z., 2009. The effect of diets containing soybean meal, soybean protein concentrate and soybean protein isolate of different oligosaccharide content on growth performance and gut function of young turkeys. Poultry Sci. 88 , 2132-2140

Jankowski J., Mikulski D., Zduńczyk Z., Mikulska M., Juśkiewicz J., 2012. The effect of diluting diets with ground and pelleted or with whole wheat on the on the performance of growing turkeys. J. Anim. Feed Sci. 21, 735-747

Jarosławska J., Juśkiewicz J., Wróblewska M., Jurgoński A., Król B., Zduńczyk Z., 2011. Polyphenol-rich strawberry pomace reduces serum and liver lipids and alters gastrointestinal metabolite formation in fructose-fed rats. J. Nutr. 141, 1777-1783

Jiang Z.Y., Jiang S.Q., Lin Y.C., Xi P.B., Yu D.Q., Wu T.X., 2007. Effect of soybean isoflavone on growth performance, meat quality, and antioxidant status in male broilers. Poultry Sci. 86, 1356-1362

Kamboh A.A., Zhu W.-Y., 2013. Effect of increasing levels of bioflavonoids in broiler feed on plasma anti-oxidative potential, lipid metabolites, and fatty acid composition of meat. Poultry Sci. $92,454-461$

Kandari V., Gupta S., 2012. Bioconversion of vegetable and fruit peel wastes in viable product. J. Microbiol. Biotech. Res. 2, 308312

Kołodziejczyk K., Markowski J., Kosmala M., Król B., Płocharski W., 2007. Apple pomace as a potential source of nutraceutical products. Pol. J. Food Nutr. Sci. 57, 291-295
Malencic D., Cvejic J., Miladinovic J., 2012. Polyphenol content and antioxidant properties of colored soybean seed from central Europe. J. Med. Food 15, 89-95

Massini L., Rico D., Belen A., Diana M., Barry-Ryan C., 2013. Valorization of apple peels. Eur. J. Food Res. Rev. 3, 1-15

Mateos G.G., Jimenez-Moreno E., Serrano M.P., Lazaro R., 2012. Poultry response to high level of dietary fibre source varying in physical and chemical characteristics. J. Appl. Poultry Res. 21, 156-174

Matoo F.A., Bhat G.A., Banday M.T., Ganai T.A.S., 2001. Performance of broiler fed on apple pomace diets supplemented with enzymes. Indian J. Anim. Nutr. 18, 349-352

Mayer A.M., 1997. Historical changes in the mineral content of fruits and vegetables. Brit. Food J. 99, 207-211

McDougall N.R., Beames R.M., 1994. Composition of raspberry pomace and its nutritive value for monogastric animals. Anim. Feed Sci. Tech. 45, 139-148

NRC, 1994. Nutrient Requirements of Poultry. $9^{\text {th }}$ revised Edition. National Academic Press. Washington, DC

Perez-Jimenez J., Neveu V., Vos F., Scalber A., 2010. Identification of the 100 richest dietary sources of polyphenols: an application of the Phenol-Explorer database. Eur. J. Clin. Nutr. 64, S112-S120

Sehm J., Treutter D., Lindermayer H., Meyer H.H.D., Pfaffl M.W., 2011. The influence of apple pomace- or red-grape pomace on blood parameters, bacterial colonization, and marker gene expression piglet white blood cells. Food Nutr. Sci. 2, 366-376

Singleton V.L., Rossi J.A., 1965. Colorimetry of total phenolics with phosphomolybdic-phosphotungstic acid reagents. Amer. J. Enol. Viticult. 16, 144-153

Smulikowska S., Rutkowski A. (Editors), 2005. Recommended Allowances and Nutritive Value of Feedstuffs - Poultry Feeding Standards (in Polish). $4^{\text {th }}$ Edition. The Kielanowski Institute of Animal Physiology and Nutrition, PAS, Jabłonna (Poland)

Sójka M., Klimczak E., Macierzyński J., Kołodziejczyk K., 2013. Nutrient and polyphenolic composition of industrial strawberry press cake. Eur. Food Res. Technol. 237, 995-1007

Statsoft Inc., 2007. STATISTICA (data analysis software system). Ver. 8. www.statsoft.com

Suarez B., Alvarez A.L., Garcia Y.D., del Barrio G., Lobo A.P., Parra F., 2010. Phenolic profiles, antioxidant activity in vitro antiviral properties of apple pomace. Food Chem. 120, 339-342

Vulic J.J., Tumbas V.T., Savatovic S.M., Dilas S.M., Cetcovic G.S., Canadanovic-Brunet J.M., 2011. Polyphenolic content and antioxidant activity of the four berry fruit pomace extract. Acta Periodica Technol. (APTEFF) 42, 271-279

Zduńczyk Z., Jankowski J., Juśkiewicz J., Lecewicz A., Slominski B., 2010. Application of soybean meal, soy protein concentrate and isolate differing in a-galactosides content to low- and high-fibre diets in growing turkeys. J. Anim. Physiol. Anim. Nutr. 94, 561-570

Zduńczyk Z., Jankowski J., Rutkowski A., Sosnowska E., Drażbo A., Zduńczyk P., Juśkiewicz J., 2014. The composition and enzymatic activity of gut microbiota in laying hens fed supplemented with blue lupine seeds. Anim. Feed Sci. Tech. $191,57-66$ 